\title{
Physico-chemical Properties and Fatty Acids Composition of Bitter and Sweet Lupine Seed
}

\author{
IKHLAS IBRAHIM KHALID' ${ }^{1}$ and SIRELKHATIM BALLA ELHARDALLOU ${ }^{2 *}$
}

${ }^{1}$ Faculty of Engneeringf and Technology, University of Gezira, Sudan. ${ }^{2}$ Faculty of Urban Studies, Alzaeem Alazhari University, Sudan.

${ }^{*}$ Corresponding author E-mail: sirballa@yahoo.com

http://dx.doi.org/10.13005/ojc/350332

(Received: February 17, 2019; Accepted: May 11, 2019)

\begin{abstract}
This study describes the constituents and properties of bitter lupine (BL) (Lupinus termis) and sweet lupine (SL) (Lupinus albus) seed oils in addition to oligosaccharides content in seed flour; each can be beneficial for consumers. There was a significant difference in saponnification number and ester value of both oils. The peroxide value was found $(1.80 \pm 0.20 \mathrm{meq} / \mathrm{kg}$ in $\mathrm{BL}$ seed oil compared to $1.89 \pm 0.29 \mathrm{meq} / \mathrm{kg}$ in SL seed oil. Fatty acids (FA) composition showed that total unsaturated FAs were higher, (88.33 \%) in BL seed oil than (87.25\%) in SL seed oil; both values markedly higher than saturated FA content. The major FA in both samples is oleic FA, $(50.23 \%)$ in $\mathrm{BL}$ and $45.00 \%$ in SL. Essential FAs were found higher (39.80 \%) in SL; compared to (36.11) in BL. Total phenols were significantly higher in BL seed oil $(58.99 \mathrm{mg} / \mathrm{kg})$; than.SL seed oil $(50.95$ $\mathrm{mg} / \mathrm{kg}$ ). The oil classes: triglycerides, free FA steroids and alcohols were found higher in SL seed oil; while hydrocarbons, mono-glycerides, di-glycerides and phospholipids were higher in BL seed oil. Total oligosaccharides were found significantly higher $(9.74 \pm 0.20 \mathrm{~g} / 100 \mathrm{~g})$ in BL flour compared to $8.99 \pm 0.10 \mathrm{~g} / 100 \mathrm{~g}$ in SL flour; with stachyose in concentrations of $3.9 \pm 0.10 \mathrm{~g} / 100 \mathrm{~g}$ and $3.88 \pm$ $0.03 \mathrm{~g} / 100 \mathrm{~g}$; respectively.
\end{abstract}

Keywords: Bitter lupine, Sweet lupine, Physical properties, Fatty acids, Oligosaccharides, Oil classes, Oil properties.

\section{INTRODUCTION}

Lupine is a leguminous plant that grows in different climates and soils. It is a potential source of protein oil and pharmaceutical purposes ${ }^{1,2}$. Like other legumes, lupine seeds are characterized by higher values of protein, minerals and dietary fiber. Protein in lupine sees, $(38 \%)^{3}$ is higher than other legumes and close to soy protein $\%^{3}$.
Lupine is a neglected legume with high protein content and fat like sesame ${ }^{4}$. Lupine seeds, with high protein and dietary fibre, are a considerable human food and animal feed ${ }^{5}$.

Lupine is lower in anti-nutritional factors than soya beans trypsin inhibitors and hemaglutinnins are practically absent $6,7,8,9$. Lupine seed protein showed many essential amino acid deficiencies with

This is an Open Access article licensed under a Creative Commons license: Attribution 4.0 International (CC- BY). Published by Oriental Scientific Publishing Company @ 2018

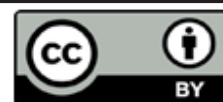


tryptophan being the most limiting. It also revealed a high amount of lysine and low amount of sulphurcontaining amino acids with a chemical score (CS) of $47-59 \%{ }^{10}$. CS is ratio of the amount of an essential amino acid in food protein to the amount of the same amino acid in a reference pattern ${ }^{11}$.

Plant fats and oils are widely used in foods for salad dressing, frying, margarine, ice cream manufacture and cooking. Lupine oils are characterized by balanced fatty acid (FA) composition with total saturated FA of about $10 \%$ and total unsaturated FA $90 \%{ }^{12}$. Lupine FA composition is mainly unsaturated with oleic and linoleic FA comprising $86 \%$ of whole oil ${ }^{13}$. The alkaloid content of lupine seed varies according to cultivar, soil type and cultivation season ${ }^{14}$. Lupine oils are characterized by balanced FA composition. Lupine seed flour is used in different cereal products as pasta, crisp, bread, cookie and cake ${ }^{15}$.

\section{MATERIALS AND METHODS}

Bitter lupine (Lupinus termis) and Sweet lupine (Lupinus albus) seeds were collected from Cairo city Egypt. They were cleaned, and rendered free of dust and foreign bodies, stored in polyethylene bags and kept in refrigerator ready for use.

\section{Preparation of Lupine seed flour}

Lupine seeds were crushed using household mill (Braun, Germany); defatted by soaking in n-hexane (Boiling point $67^{\circ} \mathrm{C}$ ) for $48 \mathrm{~h}$ with several changes of the solvent. The defatted flour was air dried at room temperature $\left(27^{\circ} \mathrm{C}\right)$; ground to pass through a 60 mesh and kept in refrigerator.

\section{Preparation of Lupine seed oil}

Ground whole seeds in $n$-hexane (BP. $40-60^{\circ} \mathrm{C}$ ) at room temperature for $48 \mathrm{~h}$ with several solvent changes, followed by evaporation using rotary evaporator (ROT. VSAC. EVA. RVA. 64, Czechoslovakia). Oil samples stored in dark tightly fitting glass bottles and kept in refrigerator ready for analysis.

\section{Physical properties of lupine seeds}

1. Seed index (Weight of 100-seeds): Triplicate of random samples of 100 seeds were weighed. And the average was reported.

2. Hulls and kernel percentages: Dry seed samples were weighed and separated manually into hulls and kernels. The percentage of both kernels and hulls was determined on dry basis. Three samples were measured and the average was recorded.

3. Relative density of seeds: It was determined using the methods of Youssef 18.100 -seeds of known weight were placed in a graduated cylinder containing $200 \mathrm{ml}$ distilled water. The increase in volume was calculated as follows:

Relative density $=$ The weight of seed $(\mathrm{g})$

$$
\text { The volume of seed }(\mathrm{ml})
$$

\section{Thickness and diameter}

Micrometer was used to measure both thickness and diameter.

\section{Physical properties of lupine oil}

1. Specific gravity: The specific gravity of oil samples was determined using $10 \mathrm{ml}$ pycnometer at $20^{\circ} \mathrm{C}$ according to the method of $\mathrm{AOCS}^{17}$.

2. Relative index: Relative index of the oil samples was measured using a Refractometer (CARI ZEISS JENA GDR) at $25^{\circ} \mathrm{C}$ according to the method of AOCS ${ }^{17}$.

3. Melting point: The melting point of oils samples was estimated using a hot plate microscope having thermometer, heating was adjusted to raise the temperature by $1^{\circ} \mathrm{C}$ every 2 minutes.

4. Viscosity: The viscosity of oil samples was measured as $\mathrm{cm}$ pois using viscometer $\mathrm{ICI}$ Co Research equipment - London at $50^{\circ} \mathrm{C}$.

5. Colour: The colour of oil samples was determined by Lovibond tintometer using a 5.25 inch cell. The yellow filter was fixed at 35 and the intensity of red was measured according to the $\mathrm{AOCS}^{17}$.

\section{Proximate Composition of lupine seed flour}

ICC Standard Methods ${ }^{16}$ were used.

Moisture content was determined by drying the sample flour at $105^{\circ} \mathrm{C}$ to a constant weight ${ }^{16}$. Ash content was determined by calcination at $900^{\circ} \mathrm{C}^{16}$ Nitrogen content was determined using Kjeldahil method with factor of 5.7 to evaluate protein content ${ }^{4}$. The total lipid content was determined by extraction using hexane in soxhlet apparatus ${ }^{16}$. Starch content was determined using a polar metric method ${ }^{17}$. All measurements were made in triplicate and calculated on dry weight basis. 


\section{Chemical characterization of lupine seed oil}

The values of acid, peroxide, saponnification and iodine were determined ${ }^{19}$.

\section{Fatty acids composition}

Methyl esters of crude oils were prepared using $1 \% \mathrm{H}_{2} \mathrm{SO}_{4}$ in absolute methyl alcohol ${ }^{19}$. A Perkin - Elmer gas chromatography (Model F22) with a flame ionization detector was use, $\mathrm{d}$ in the presence of nitrogen as a carrier gas. A glass column (2 $\mathrm{mx} 2.5 \mathrm{~mm}$ ) packed with Chrome Q 80/100 mesh at a temperature of $270^{\circ} \mathrm{C}$ was used. Standard fatty acids methyl esters, were used for identification. The area under each peak was measured and the percentage expressed in reference to total area.

\section{Oligosaccharides content}

Oligosaccharides, extracted from the flour samples (10 $\mathrm{g}$ of flour sample, placed in $150 \mathrm{ml}$ of boiling distilled water and kept at boiling for $30 \mathrm{~min}$ ) were determined using HPLC ${ }^{20}$.

\section{Statistical analysis}

All results expressed as the mean of three determinations. The data were statistically analyzed using analysis of variance and least significant difference ${ }^{21}$. Significant difference was determined at the $\mathrm{P}<0.05$ level. Means \pm standard deviations of three replicates were used ${ }^{22}$

\section{RESULTS AND DISCUSSION}

\section{Physical Properties of lupine seed oil}

Physical properties of BL and SL seeds such as seed index hull percentage, kernel percentage, relative density, seed dimensions (length, width, and thickness) are presented in Table (1). BL seeds were significantly $(P \leq 0.05)$ higher in most physical properties (except kernel percentage) than SL seeds.

Table 1: Physical properties of bitter and sweet lupine seeds

\begin{tabular}{lccc}
\hline Property & $\begin{array}{c}\text { Bitter lupine } \\
\text { seed }\end{array}$ & $\begin{array}{c}\text { Sweet lupine } \\
\text { seed }\end{array}$ & LSD \\
\hline Seed index $(\mathrm{g})$ & $22.41^{\mathrm{b}} \pm 1.15$ & $19.93^{\mathrm{a}} \pm 0.98$ & 2.44 \\
Hulls \% & $12.60^{\mathrm{b}} \pm 0.41$ & $10.55^{\mathrm{a}} \pm 0.31$ & 0.85 \\
Kernels \% & $88.39^{\mathrm{a}} \pm 0.44$ & $89.09^{\mathrm{b}} \pm 0.75$ & 0.98 \\
Relative density $\left(\mathrm{g} / \mathrm{cm}^{3}\right)$ & $1.03^{\mathrm{b}} \pm 0.07$ & $0.77^{\mathrm{a}} \pm 0.05$ & 0.14 \\
Seed length $(\mathrm{mm})$ & $10.33^{\mathrm{b}} \pm 0.35$ & $8.10^{\mathrm{a}} \pm 0.46$ & 0.94 \\
Seed width $(\mathrm{mm})$ & $8.52^{\mathrm{b}} \pm 0.31$ & $7.37^{\mathrm{a}} \pm 0.21$ & 0.60 \\
Seed thickness $(\mathrm{mm})$ & $4.56^{\mathrm{b}} \pm 0.11$ & $3.71^{\mathrm{a}} \pm 0.20$ & 0.37 \\
\hline
\end{tabular}

Same letter in any raw (sample) signs for non-significant difference. *Mean \pm standard deviation of 3 determinations. LSD = Least significant difference

Table 2 shows some physical properties of BL and SL seed oils. No significant $(\mathrm{P} \leq 0.05)$ difference was observed between BL and SL seed oils in their Relative index, specific gravity, melting point and Viscosity. These results agree well with those of lupinus termis seed oil ${ }^{23}$ for relative index $(1,471-1473)$, specific gravity (0.6169-0.9240) and colour (9R/1.3B).

Table 2: Physical properties of bitter and sweet lupine seed oils

\begin{tabular}{lccc}
\hline Property & Bitter lupine seed & Sweet lupine seed & LSD \\
\hline $\begin{array}{l}\text { Relative index } \\
\left(25^{\circ} \mathrm{C}\right)\end{array}$ & $1.4681^{\mathrm{a}} \pm 0.002$ & $1.4585^{\mathrm{a}} \pm 0.002$ & 0.003 \\
Specific gravity & $0.868^{\mathrm{a}} \pm 0.03$ & $0.92^{\mathrm{a}} \pm 0.07$ & 0.123 \\
$\left(25^{\circ} \mathrm{C}\right)$ & & & \\
Melting point $\left({ }^{\circ} \mathrm{C}\right)$ & $5.2^{\mathrm{a}} \pm 0.06$ & $5.1^{\mathrm{a}} \pm 0.06$ & 0.009 \\
Viscosity (cm pois) & $40.7^{\mathrm{a}} \pm 0.15$ & $40.8^{\mathrm{a}} \pm 0.32$ & 0.570 \\
${ }^{*}$ Colour & $9.0 \mathrm{R} / 5,5 \mathrm{~B}$ & $7.0 \mathrm{R} / 3.7 \mathrm{~B}$ & \\
\hline
\end{tabular}

Same letter in any raw (sample) signs for non-significant difference. Mean \pm standard deviation of 3 determinations. LSD $=$ Least significant difference. ${ }^{* *}$ Means \pm standard deviation of 2 determinations

\section{Proximate analysis}

Proximate analysis of whole $\mathrm{BL}$ seed flour showed $43.6 \%$ total protein ( $\mathrm{N} 6,25) ; 9.6 \%$ crude lipids; $12.5 \%$ crude fiber; $3.2 \%$ ash and $31.1 \%$ total carbohydrates (by difference). Proximate analysis of whole SL seed flour showed $38.6 \%$ total protein (N X6,25); $12.4 \%$ crude lipids; $11.3 \%$ crude fiber; $3.3 \%$ ash and $34.4 \%$ total carbohydrates (by difference).

\section{Chemical properties of lupine seed oil}

Acid value (AV), an important indicator of vegetable oil quality, is expressed as the amount of $\mathrm{KOH}$ (in mg) necessary to neutralize free fatty acids found in $1 \mathrm{~g}$ of oil ${ }^{23,24}$.

Table 3 shows some chemical properties of lupine seed oils. There was no significant difference in both studies oils with respect to AV peroxide value and saponnification value. Howerver, there is a significant difference in total phenols, iodine value and ester value.

Table 3: Chemical properties of bitter and sweet lupine seed oils

\begin{tabular}{lcc}
\hline Properties & Bitter & Sweet \\
\hline Acid value & $0.93^{\mathrm{a}} \pm 0.05$ & $0.857^{\mathrm{a}} \pm 0.01$ \\
Peroxide value $\mathrm{meq} / \mathrm{kg}$ & $1.80^{\mathrm{a}} \pm 0.20$ & $1.89^{\mathrm{a}} \pm 0.29$ \\
lodine value $\mathrm{ml} / 100 \mathrm{~g}$ & $115^{\mathrm{b}} \pm 2.0$ & $110^{\mathrm{a}} \pm 2.60$ \\
Total phenols $(\mathrm{mg} / \mathrm{kg})$ & $58.99^{\mathrm{b}} \pm 1.30$ & $50.45^{\mathrm{a}} \pm 1.99$ \\
Saponification value & $193.54^{\mathrm{a}} \pm 3.50$ & $190.0^{\mathrm{a}} \pm 1.33$ \\
Ester value & $190.00^{\mathrm{a}} \pm 3.60$ & $185.05^{\mathrm{b}} \pm 1.44$ \\
\hline
\end{tabular}

Same letter in any raw (sample) signs for non-significant difference. Mean + standard deviation of 3 determinations

In studies, 2012, ${ }^{25} \mathrm{AV}$ was reported as significantly higher in $\mathrm{BL}$ seed oil $(0.935 \pm 0.07)$ than SL seed oil, $(0.835 \pm 0.08)$; while ester value (in agreement with this study) was significantly lower in 
SL seed oil as compared to BL seed oil. The peroxide values of both oils recorded in present study are well below the range of those reported by Codex Alimmantarius Commission (2001) i.e $<10 \mathrm{meq} / \mathrm{kg}$ for soybean, rapeseed, cotton seed and coconut oils. The iodine values observed in both $\mathrm{BL}$ (115.4 $\pm 2.06)$ and SL $(110.7 \pm 2.15)$ seed oils were higher than that earlier reported ${ }^{26}$ as $96 \%$.

\section{Fatty acids composition}

Table 4 shows fatty acid composition of $B L$ and $S L$ seed oils There was a significant variation between the two types. Oleic acid was significantly higher in BL oil $(50.23 \%)$ than SL seed oil (45\%); while linoleic acid is significantly lower in BL $(22 \%)$ and higher in SL (24.9\%); with no significant difference in linolenic FA content: (13.5\%) and (14.9\%) for BL and SL seed oil, respectively. However, the content of linolenic acid in both types of lupine seed oils are far less than that reported in flax seed oil $(47 \%)^{27}$.

\section{Lupine seed oil classes}

No variations were observed in percentage of oil classes (like hydrocarbons, triglycerides, free fatty acids and steroids) in both BL and SL seed oils. However, BL seed oil showed higher content of diglycerides (Table 5).

Table 4: Fatty acids composition of bitter and sweet lupine seed oils

\begin{tabular}{lcc}
\hline Saturated and unsaturated & \multicolumn{2}{c}{ Lupine seed flours oil } \\
Fatty acids \% & Bitter lupine & Sweet lupine \\
& $0.140 \pm 0.03^{\mathrm{a}}$ & $0.199 \pm 0.03^{\mathrm{a}}$ \\
\hline Myristic $\mathrm{C}_{14: 0}$ & $8.990 \pm 0.69^{\mathrm{a}}$ & $7.612 \pm 0.69^{\mathrm{a}}$ \\
Palmitic C $_{16: 0}$ & $2.001 \pm 0.14^{\mathrm{a}}$ & $1.711 \pm 0.14^{\mathrm{b}}$ \\
${\text { Stearic } \mathrm{C}_{18: 0}}$ & $2.123 \pm 0.27^{\mathrm{a}}$ & $2.657 \pm 0.27^{\mathrm{a}}$ \\
Arachidinic $_{20: 0}$ & $50.234 \pm 0.62^{\mathrm{a}}$ & $45.00 \pm 0.62^{\mathrm{b}}$ \\
Oleic C $_{18: 1}$ & $22.546 \pm 1.18^{\mathrm{b}}$ & $24.900 \pm 1.18^{\mathrm{a}}$ \\
Linoleic C $_{18: 2}$ & $13.564 \pm 0.67^{\mathrm{a}}$ & $14.897 \pm 0.67^{\mathrm{a}}$ \\
Linolenic C $_{18: 3}$ & $0.440 \pm 0.11^{\mathrm{a}}$ & $0.660 \pm 0.11^{\mathrm{a}}$ \\
Palmitoleic C & $1.551 \pm 0.12^{\mathrm{a}}$ & $1.789 \pm 0.12^{\mathrm{a}}$ \\
Arachidic C & & \\
Total saturated fatty & $13.251 \pm 0.54^{\mathrm{a}}$ & $12.179 \pm 0.54^{\mathrm{a}}$ \\
acids (TSFA) & & \\
Total unsaturated fatty & $88.330 \pm 0.54^{\mathrm{a}}$ & $87.246 \pm 0.54^{\mathrm{a}}$ \\
acids (TUFA) & & \\
TUFA)/ (TSFA) $_{\text {Total essential fatty acid }}$ & $36.114 \pm 0.84^{\mathrm{b}}$ & $39.797 \pm 0.84^{\mathrm{a}}$ \\
\hline
\end{tabular}

Same letter in any raw (sample) signs for non-significant difference

Table 5: \% of oil classes in bitter and sweet lupine seed oils

\begin{tabular}{lcc}
\hline Class & \multicolumn{2}{c}{ Lupine seed oil } \\
& Bitter & Sweet \\
\hline Hydrocarbons & $1.00 \pm 0.045^{\mathrm{a}}$ & $0.91 \pm 0.045^{\mathrm{b}}$ \\
Free fatty acids & $9.00 \pm 0.11^{\mathrm{a}}$ & $9.22 \pm 0.11^{\mathrm{a}}$ \\
Steroids & $4.20 \pm 0.15^{\mathrm{a}}$ & $4.50 \pm 0.15^{\mathrm{a}}$ \\
Monoglycerides & $2.00 \pm 0.25^{\mathrm{a}}$ & $1.50 \pm 0.25^{\mathrm{a}}$ \\
Diglycerides & $8.00 \pm 0.50^{\mathrm{a}}$ & $7.00 \pm 0.50^{\mathrm{a}}$ \\
Triglycerides & $74.00 \pm 0.335^{\mathrm{a}}$ & $74.67 \pm 0.335^{\mathrm{a}}$ \\
Phospholipids & $2.20 \pm 0.045^{\mathrm{a}}$ & $2.11 \pm 0.045^{\mathrm{a}}$ \\
Alcohols & $0.21 \pm 0.16^{\mathrm{b}}$ & $0.53 \pm 0.16^{\mathrm{a}}$ \\
\hline
\end{tabular}

Same letter in any raw (sample) signs for non-significant difference

\section{Oligosaccharides content}

Oligosaccharides are the most abundant soluble sugars; it was reported that sucrose and verbascose content in legume seeds are genetically affected whereas raffinose and stachyose content is mostly guided by environmental conditions ${ }^{28}$.

As shown in Table 6 there is a significant difference between the content of each of raffinose and verbascose in flour of $B L$ and SL seed. On the other hand, there is no significant difference between sucrose and stachyose content in the two studied samples. In Dolichos labab, legume seeds (as\% of dry weight): stachyose $(2.68 \pm 0.13)$, raffinose $(0.84 \pm 0.03)$ and sucrose $(1.49 \pm 0.06)$ was reported $^{28}$.

Table 6: Oligosaccharides content of bitter and sweet lupine seed flours ( $\mathrm{mg} / 100 \mathrm{~g}$ sample)

\begin{tabular}{lccc}
\hline Sugar & Bitter & Sweet & LSD \\
\hline Sucrose & $1.99 a \pm 0.10$ & $2.00 \mathrm{a} \pm 0.11$ & 0.213 \\
Stachyose & $3.90 \mathrm{a} \pm 0.10$ & $3.88 \mathrm{a} \pm 0.03$ & 0.151 \\
Raffinose & $1.40 \mathrm{~b} \pm 0.06$ & $0.89 \mathrm{as} \pm 0.07$ & 0.166 \\
Verbascose & $2.45 \mathrm{~b} \pm 0.05$ & $2.22 \mathrm{a} \pm 0.05$ & 0.149 \\
Total & $9.74 \mathrm{~b} \pm 0.20$ & $8.99 \mathrm{a} \pm 0.10$ & 0.388 \\
\hline
\end{tabular}

Same letter in any raw (sample) signs for non-significant difference. Mean + standard deviation of 3 determinations. LSD = Least significant difference

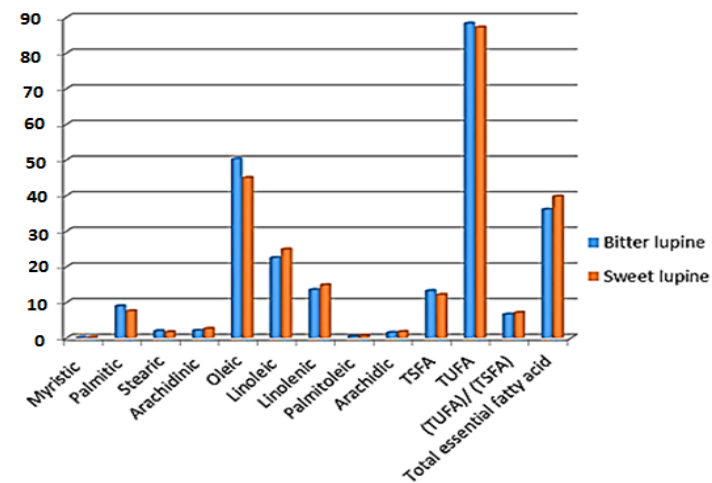

Fig. 1. Fatty acids composition of bitter and sweet lupine seed oils

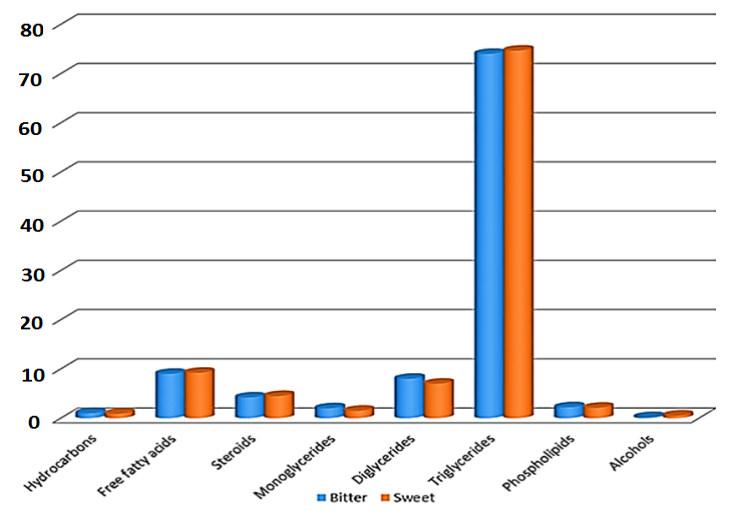

Fig. 2. Oil classes $\%$ of bitter and sweet lupine seed 


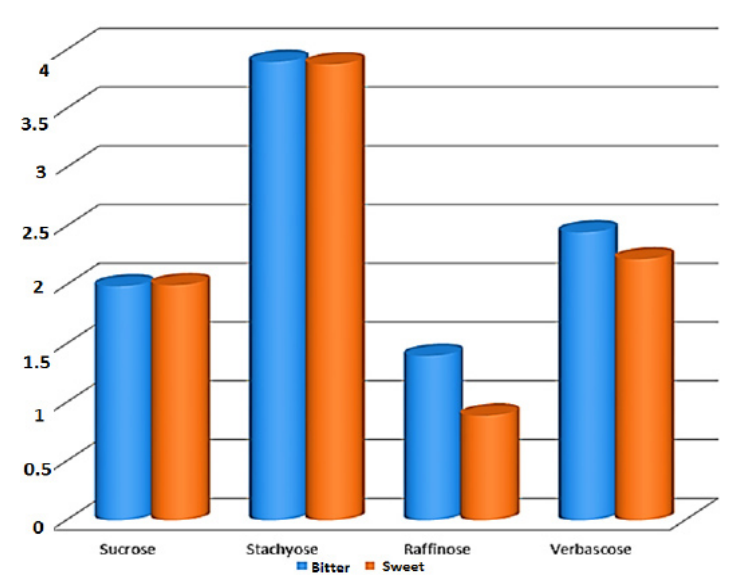

Fig. 3. Oligosaccharides content of bitter and sweat lupine seed flours ( $\mathrm{mg} / 100 \mathrm{~g}$ sample)

\section{CONCLUSION}

The BL seed weight was found $(22.41 \mathrm{~b}$ $\pm 1.15)$, significantly more than SL seed weight $(19.93 a \pm 0.98)$; with hull \% of $(12.60 b \pm 0.41)$ and (10.55 $\mathrm{a} \pm 0.31$ ); respectively. Essential FAs were found higher (39.80\%) in SL seed oil; compared to (36.11) in BL. The major FA in both samples is oleic FA, $(50.23 \%)$ in BL and $45.00 \%$ in SL. Fatty acids (FA) composition showed that total unsaturated FAs were higher, (88.33\%) in BL seed oil than (87.25\%) in SL seed oil; both values markedly higher than saturated FA values. Total phenols were significantly higher in BL seed oil $(58.99 \mathrm{mg} / \mathrm{kg})$; than SL seed oil $(50.95 \mathrm{mg} / \mathrm{kg})$. Total oligosaccharides were found significantly higher $(9.74 \pm 0.20 \mathrm{~g} / 100 \mathrm{~g})$ in BL flour compared to $8.99 \pm 0.10 \mathrm{~g} / 100 \mathrm{~g}$ in SL flour; with raffinose concentrations of $(1.40 \mathrm{~b}+0.06 \mathrm{~g} / 100 \mathrm{~g})$ and $(0.89 \mathrm{as}+0.07 \mathrm{~g} / 100 \mathrm{~g})$; respectively.

\section{ACKNOWLEDGMENT}

This research work was carried at National Research Centre, Cairo, Egypt and financed by Gezira University, Sudan with ample gratitude and thanks.

\section{Confilicts of Interest}

The authors declare no confilict of interest.

\section{REFERENCES}

1. Gaultier, F., Foucault-Bertaud, A., Lamy, E., Ejeil, A. L., Dridi, S. M., Piccardi, N.,.. Effects of a vegetable extract from Lupinus albus (LU105) on the production of matrix metalloproteinase (MMP1, MMP2, MMP9) and tissue inhibitor of metalloproteinases (TIMP1, TIMP2) by human gingival fibroblasts in culture. Clinical Oral Investigation., 2003. 7(4), 198-205.

2. Farrell, D. J., Perez-Maldonado, R. A., Mannion, P. F. Optimum inclusion of field peas, faba beans chick peas and sweet lupins. Poultry Science., 1999. 40(5), 674-680.

3. Getachew, P., Umeta, M., Retta, N., Bekele, T. and Haki, D. G. Proximate composition and anti-nutritional factors of traditionally processed white lupine (Lupinus albus L.) Fabaceae grown in Ethiopia. Ethiopian Journal of Biological Science., 2012, 11, 133-146.

4. Astri, A. Genetic resources of sesame; present and future perspectives. In Biodiversity in Asia;conservation, evaluation and improvement. Sesame. R. k. Arora; K.W. Reity (eds)., 1994, 25-39. New Delhi, India.

5. Petterson, D. N. Composition and food uses ofS lupins In Lupins as crop plants, Biologym Production and Utilization, J. S.
Glasstone, J.S.Arkins and C.Hamblin (eds), Cab International, New York., 1998, 356-358.

6. Hill, G. D. The composition and nutritive value of lupin seed. Nutr. Abstr. Rev. (B)., 1977, 47, 511-529.

7. Hill, G. D. Recent developments in the use of lupins in the animal and human nutrition. In Proc. Fourth Intl Lupin Conf. Dept. of Agrics.: Geraldton, Western Australia., 1986, 40-62.

8. Scnoeneberger, H., Gross, R., Crener, H. D., and Elmadfa, I. The protein quality of lupins (Lupinus mutabilis) alone and in combination with other protein sources. Qual. Plant. Foods Hum. Nutr., 1983, 32, 133-144.

9. Mathews, R. H. In Legumes: Chemistry, Technology and Human Nutrition. R.H. Matthews, ed. Marcel Dekker: New York., 1989, 271-281.

10. Dervas G, Doxastakis G, Zinoviadi S, Triandatafilikoss $N$. Lupin flour addition to wheat flour doughs and effect on rheological properties. Food Chem., 1999. 66, 67-73.

11. Williams, W., and Mc Gibbon, R. Environmental effect on seed oil percentage and fatty acid composition in white lupin. J. Agric. Sci., 1980. 95, 597-602. 
12. Gladstones, J. S. Lupins as plant crops. Field Crop Abs., 1970, 23, 123-148.

13. Erbas M.; Certel M. S. and Uslu, M.K. Some chemical properties of white lupin seeds (Lupinus albus L.) Food Chem., 2005, 89, 341-345.

14. Peterson, D. N. The use of lupins in feeding systems. Review. Asian Australian J Animal Sciences., 2000, 2000(13), 861-882.

15. Davidek, J., J. Hrdlicka, M. Karvanek, J. Pokorny and J. Velisek,. "Laboratory handbook for foodstuffs, CR, SNTL-Alfa, Prague., 1981.

16. Cauvain and Young.The ICC (International Organization of Cereal Chemistry) handbook of cereals, flours, dough and product testing. Methods and applications. Baketram, High Wicomb, Bucking hamshare, UK., 2001.

17. AOCS. Official and Tentative Methods of the American Oil Chemist's Society. (3rd Ed.) AOCS, Champaign., 1973, 1.

18. Youssef, M. M. A study of factors affecting the cookability of faba bean (Vicia faba L.) Ph. D. thesis. Faculty of Agric. Alexandria University, Egypt., 1978.

19. Chalvardjian, A.. Fatty acids of brown and yellow fat in rats. Biochemical J., 1964, 90, 518-521.

20. Knudsen, I. M. HPLC determination of oligosaccharides in leguminous seeds. J. Science of Food and Agriculture., 1986, 37, 560-166.

21. SAS/STAT Users Guide: Statistics, version. SAS Institute: Cary, NC, USA., 1996.

22. Pallant, J. SPSS Survival, 2ND edn Maidenheah Open University Press., 2005.

23. EL-Damaty E.H. Hasheme, and Omer, A. Physical and chemical characteristics of crude lupin seed oil . Egypt. J. Food Sci., 1986, 14(1), 157-164.

24. Firestone, D. (Ed). Free Fatty Acids. Official Methods and Recommended Practices of the American Oil Chemists Society, $4^{\text {th }}$ ed., American Oil Chemists Society. Champaign, USA., 1996.

25. Alamri, M.S. Characterization of lupin seed oils extracted from bitter and sweet type. Pakistan J Food Science., 2012, 22(3), 161-167.

26. Zhang, Z. S. ; Wang, L. J. ; Li, D. Li, S.J.; Zkan, N. Charachteristics of flax seed oil from two different flax plants. International J Food Properties., 2011, 14(6), 1286-1296.

27. Lauro, M. F. The white lupine flour and oil. $J$ American Oil Chemists' Society., 1934, 11 (9), 196-197.

28. Chao, C. F.; Cheung, C. K. and Woog, Y.S. Chemical composition of three underutilized legume seeds grown in China. Food Chemistry., 1998, 61(4), 505-509. 